\title{
A LAW TEACHER LOOKS AT HIS TRADE
}

\author{
BRIAN COOTE*
}

Taking a heretical look at legal training and practice in New Zealand, Prof. Coote details criticisms that might well apply to other common law jurisdictions, including Canada. He describes the need for and predicts a "great revolution," in three aspects of the legal system, but warns of the difficulties ahead.

\section{INTRODUCTION}

So that I might get a picture of how the lawyers' trade looks through someone else's eyes, I have recently gone through the published proceedings for the last twenty years of the Society of Public Teachers of Law in England. I have also looked at passages from a recent book called Lawyers and the Courts by Abel-Smith and Stevens. A picture has emerged from all this reading which might well be considered shocking by anyone except, perhaps, a law teacher.

Take first the common law which we espouse. Whenever our lawyers forgather, it is certain that someone will extoll the glories of the common law, its supposed adaptability and practicality, its empiricism and its respect for human freedom and dignity. Few of these claims really stand up to analysis. It is true that the common law is one of the two great world systems of law. It is equally true that no country in the world has ever adopted it voluntarily.

Then there are the persons concerned. The common law judges have great and well-merited prestige but this may be at least partly explained by the fact that there are extraordinarily few of them. Their numbers and prestige are sustained at this level, it may be argued, largely because common law litigation is so ruinously expensive. As for common law practitioners, they have, historically, been persons with little or no formal education in the law they practice. Even today, very many of them can see no value in a university education as such, unless possibly in some discipline other than law. As a body, they have seen their position and influence declining and the scope of their work narrowing, as other professions and groups have taken over many of their traditional roles.

As for law teachers, they have never had much prestige or influence to lose. Regarded by the profession as hopelessly academic and by their university colleagues as hopelessly unacademic, a large proportion of them seem to lack confidence in the merit and standing of their own discipline.

Admittedly, this rather dismal picture is an English one. But I think if we were honest we would recognize some parallels in New Zealand. One naturally hesitates to pass judgment so close to home, but while the New Zealand universities have for a long time provided legal instruction for the profession I doubt whether many of my generation and before would claim to have had much more than a polytechnic training in fact. The profession has, through the whole history of this country, regarded university influence on legal education with suspicion and has fought

- LL.M. (N.Z.), Ph.D. (Cantab.). Professor of Law, University of Auckland. This paper is the text of an Inaugural Lecture delivered to the University of Auckland, New Zealand, on September 19, 1967. 
every encroachment the law schools have made. The profession's low opinion of law teaching seems to have been shared by the universities themselves. Even today, the law faculties remain amongst the cheapest to run.

My purpose in mentioning all this is not to revive old controversies or to indulge in foolish recriminations. Least of all is it to lose friends, whether new or old. What I should like to do is rather to investigate why we should have come to this pass, and, against the background of this understanding, to try to assess the present position and to make some predictions for the future.

\section{THE ORIGINS OF THE COMMON LAW SYSTEM AND THEIR CONSEQUENCES}

Like most other English institutions, the common law can be defined and understood only by reference to its history. I suppose its chief characteristic is the degree to which the whole system turns on what individual judges have said and done in previous cases. If you were to ask the man in the street what he considered a "law" to be, I expect he would reply in terms of a rule of conduct prescribed by the state and applied and enforced by the courts. "The Law" I think he would see as a set or code of such rules, more or less rationally and coherently formulated on broad considerations of policy. Lawyers brought up in the other great world legal system-that based on Roman Law-would certainly see the law in this way; as a code prescribed beforehand to be applied by the courts to the particular cases coming before them. The common law, however, originated, and still very largely works, in the reverse of the normal order. The common law started and still starts with actual litigation before a particular court. As a body of rules or of doctrines, it exists, if at all, only to the extent that it may have been declared by particular judges while they were dealing with particular disputes between particular opposing litigants. If there are to be any general principles, they must be deduced by synthesizing and generalizing from the mass of these particular decisions in particular disputes.

How did this extraordinary-one might even say perverse-system ever come into being?

I think the first determinant was the fact that the courts as we know them evolved from institutions which originally had a quite different function and intention. They became courts only because disputes had to be decided by someone. As a result, certain officers of the royal government found themselves exercising what we would now recognise as a judicial function. Again, because these institutions originated as something other than courts, the means by which aspiring litigants brought their disputes before the courts were almost inevitably inappropriate or unsuitable for their new purpose.

Of course, over the centuries the courts became more clearly identified as such, and a body of professional lawyers grew up around them; but the common law never lost the mark of its origins, mainly because, until very modern times, the system of courts was never reformed. Such changes as took place, and they were many, had to occur within the existing framework. From all this, certain vital consequences followed. 
The first and most important was that because the formal means of bringing a dispute before the court were few and inappropriate, the prime concern of any litigant was how to bring his case before the tribunal at all. If a new sort of dispute was to be heard, it was necessary somehow to twist the existing forms of action to accommodate it. The ways of doing this became progressively more and more intricate and refined as the centuries went by. This was the area where the greatest amount of legal ingenuity had to be concentrated. The chief concern of lawyers tended to be with details of procedure of a most narrow and technical nature. One result of this was that, though the universities were interested in ecclesiastical and canon law, they were not and could not be in the least interested in the arid technicalities of the native common law. Legal education was left entirely in the hands of the profession.

This in turn had its consequences. The method of legal education the profession adopted was the one you would expect in such circumstancesthe apprenticeship system. What sort of person, one may ask, does an apprenticeship system produce? Our modern experience confirms that it produces a person of the skilled artisan or tradesman type, that is to say, someone who, from his observation of his master and other tradesmen, has learned how to perform certain skilled functions but without knowing (other than intuitively) the theory behind them. He is the sort of person who will tend in a given situation to be guided by what other skilled persons have done in such situations before him.

Is it surprising, therefore, that this should describe exactly the way the common-law lawyer functioned? As a practitioner, his chief concern, as I have said, was with the practical difficulties of getting his client's case before the court. As a judge, his natural reaction in any given situation was to look to what his predecessors in similar circumstances had done before him. Inexorably, the system became a self perpetuating one. Where the raw material of the law was a host of specific decisions on particular facts, only bold academic enquiry could hope, by laying down general principles, to bring coherence and consistency to the law. But the system was not geared to produce such rationalization. With a few individual exceptions, practitioners of the law were not fitted by their education and training to do this. Such practitioners' books as there were tended to be no more than digests of cases. The universities displayed no interest in what to them appeared the arid technicalities of legal practice. For its part, the profession implicitly accepted this judgment. A technical subject required and received a technical training. The student picked up his law as questions arose in his master's practice.

Inevitably, a lawyer trained in this tradition would tend to see the law, not as a body of coherent principle, but as a set of arbitrary rules. Advance and change tended to take the form, not of the broadening of principle, but of the increasing refinement, by way of exception or contingency, of the existing rules. The law tended to become not more rationalized or more elegant, but increasingly more technical and artificial. That the system worked at all and gave any sort of satisfaction was due, I think, to three factors. First, while the judges may have started with no given law to work from, they were able at least to bring to their task broad notions of common sense and justice. Secondly, 
while they would by inclination tend to follow the precedents laid down by those who preceded them, they were not until modern times compelled to do so as a matter of dogma. Thirdly, only in modern times has law reporting become scientific. In other words, in seeking precedents to follow, judges and practitioners were confined, apart from brief written reports, to the experience of themselves and their professional brethren. In these circumstances it would have been possible to forget or ignore an uncongenial precedent.

May I sum up at this stage by saying that the common law started, not as Roman or civil law does as a body of given doctrine, but rather as an ad hoc system of deciding disputes. The doctrinal void was filled over the centuries by the judicial practice of continuing to do what earlier judges had done before. What developed was not so much a body of doctrine as a system of highly technical rules. It became self-perpetuating because, being so technical, it seemed to require a technical training. And because its practitioners had had only a technical training, they were not equipped to alter it.

\section{THE REVOLUTION THAT WENT SOUR}

In the last two hundred years, however, certain new factors have entered the scene. In the first place a group of English theoreticians arose in the first half of the nineteenth century, of whom the most important was Jeremy Bentham. Moreover, some of the works of continental jurists were translated and published in England. The specific proposals of these two groups of persons were not always adopted and, where they were adopted, not always with benign results, but they were read and they did create a climate for the rationalization of the law. The second point was that the universities at last started to take an interest in law. The new academic lawyers had few students, and those they had appear to have been generally of poor quality, but they themselves were men of great ability and they wrote books. It was people like Blackstone, Dicey, Anson and Pollock who began the actual rationalization of the law. The third factor was the abolition, during the nineteenth century, of the worst procedural technicalities of the old system. The courts were freed at last to devote their energies principally to the substance of the disputes before them. Fourthly, the professions at last began to require some degree of formal education as a prerequisite for legal practice.

The stage seemed set for a great revolution in which an educated profession and the new breed of legal scholars might together evolve for England, as for this country, a rational, just and coherent body of law. In the event, of course, it has not really worked out that way. Even today, legal professional training in England is still fairly primitive. The universities themselves still have a long way to go. The profession and legal scholars have never really come together. Creative law making has passed very largely into the hands of the legislature. Why then did the revolution go sour? I believe the reasons can all be reduced to two: legal training and the doctrine of precedent.

\section{The Stare Decisis Rule}

Take precedent first. Two developments of modern times have had far-ranging effects. The first was the emergence of accurate and ex- 
tensive law reporting and the other was that the higher courts, as a matter of legal dogma, bound themselves to follow their own decisions. The emergence of accurate and extensive reporting has had the effect that the raw material of the law, the actual decisions in earlier cases, has multiplied beyond all conscience. Following earlier decisions was all very well at a time when the number of accessible decisions was few. Today they run into hundreds of thousands, even millions. Stop-gap measures, such as digests and indices, have been taken to make the system tolerable for today's generation of lawyers. Tomorrow's lawyers will no doubt resort to computers. But sooner or later the question will have to be answered whether a system evolved to meet the needs of a relatively unsophisticated rural society is really suited to the requirements of a modern commercial community.

It was scientific law reporting which to a degree made a dogmatic rule of precedent possible. Obviously, no court could bind itself to its earlier decisions unless accurate records of these were readily available. No doubt, at the time, there seemed to be good enough reasons of policy for the stare decisis rule. Essentially, the common law system was an attempt to work justice without law. But a modern commercial community is really more concerned to have law than it is to have justice. It tends to want to know, before it enters into any dealings rather than afterwards, what the law is which will govern those relationships. In a case law system, the rules of law can be certain and ascertainable in advance only if lawyers have an assurance that the decisions of the judges will be consistent with what they have done in the past. The stare decisis rule, therefore, was an attempt to provide a received or given code of law within the framework of a case system.

But the results have not really been what I imagine the originators of the rule hoped for or intended. In particular, the great benefit of certainty has proved elusive. As one might expect of a system concerned with minutiae rather than with principles, scientific reporting and analysis have shown up areas of inconsistency, conflict and uncertainty. Even today, there are important areas of the law which will remain unknowable, or at least uncertain, until some litigant is prepared to pay the price of having them decided. Another, and I think more important, result has been the way in which the stare decisis rule has inhibited both the judicial reformer and the academic lawyer. Judges wanting to reform the law have been able to do so only by using a somewhat artificial device called "distinguishing" earlier cases, that is, by finding sufficient differences between the earlier case and the case before them to allow them to hold that the earlier case was not binding. The danger of this process is that it will lead to the very kind of artificial distinction that made the earlier rules of procedure a maze of technicalities. At best, its tendency is towards particularity and away from general principle.

The others who have suffered most from the stare decisis rule are the academic lawyers. As I have said, they were faced in the nineteenth century with the immense task of distilling general principles from a mass of disparate decisions, of rationalizing and bringing coherence to the law. It is a task which is still a long way from completion. But in 
all this, the actual role of the academic lawyer has been almost wholly dictated by the stare decisis rule.

So far as analysis goes, of course, the academics have had enormous scope in more or less virgin territory. In terms of synthesis, they have been less fortunate. Generalizations, however attractive, have always to give way to contrary precedents. It follows that even where the law teacher is content to accept the present law on its own terms his scope for improving it by rationalizing and generalizing it is likely to be limited. If he should want to go further and bring to bear on the law the insights of other disciplines such as sociology, economics, anthropology, political studies and the like, he finds himself in real difficulty. Not only can he have no direct influence on the law, for it is the judges who make the law, but the judges themselves are prevented by the system from taking into account any considerations other than the decisions of their predecessors. It follows that academic law holds considerable satisfaction for analysts and antiquarians who like to fossick amongst old cases. It provides some limited satisfaction for the synthesizers and those who follow the pursuit of elegance. It offers little but frustration to those who would prefer to see the law in a wider context. It is surely ironic that the practitioners of anything as artificial as the common law should pride themselves on being practical, whilst those who would judge the law by its effects in action are pejoratively dismissed as 'academic'.

\section{Legal Training}

This brings us to the question of training the profession. We have seen that before the abolition of the old forms of action, the law itself was extraordinarily technical. The changes of the nineteenth century swept away a lot of dead wood. But it remained and still remains true that the actual practice of the legal profession is very largely technical in character. The practitioner in the courts is for most of his time concerned, not so much with the law which in the ordinary run of cases is relatively well developed because such cases have come before the courts so often, but with the task of collecting and sifting evidence, with procedure, with the techniques of negotiation and advocacy and with his relationships with his clients. Similarly, the conveyancer and commercial lawyer will be more concerned with the techniques of draftsmanship and with office administration than with theories of the nature of law. The law itself forms a necessary background to all this but, quantitatively, it is no more than a fraction of the practitioner's total concern.

This predominance of the practical or technical aspects of ordinary practice has undoubtedly coloured the attitudes of the profession to legal training, even since the reforms of the nineteenth century. Law which originates in ad hoc decisions easily acquires the appearance of a series of arbitrary rules. Lawyers who learned their law under a system of technical training would certainly see no cause to regard the law in any other light. The predominance of the technical nature of legal practice seemed to require that the greater part of a student's energies should continue to be devoted to acquiring these techniques under an apprenticeship system, whether in offices or in chambers. If the law were no more than a set of arbitrary rules, its dissemination would present no difficulties. It could quite adequately or even better be handled 
by amateur teachers, that is to say, by part-time teachers drawn from the practising profession, than by professional academics. In the matter of ordering a student's time, learning the law must give way to the more important task of learning the workings of a legal office.

We have come down to the present day, then, with a system of law which because of the stare decisis rule is still largely resistant to rationalization. We have, too, a legal profession whose members' understanding of the law has disposed them to consider it unsuited to academic treatment and whose experience of formal legal education has made them sceptical of its value.

Can I now sum up why I think the great revolution which the nineteenth century promised has not yet taken place? First, at the very time that a new breed of professional academic lawyers had made possible a rationalization of the law, the introduction of an absolute doctrine of precedent made rationalization more difficult than ever. Secondly, the stare decisis rule not only limited the effectiveness of academic lawyers; it also inhibited their very approach to their subject. Like their brethren in the practising profession, they had to accept the system as they found it. Their critical and academic energies had largely to be confined to analysis and, to some degree, to synthesis. Through them, the law continued to look in on itself. Thirdly, the legal profession, as the result of both its experience and training, was, for what seemed to it compelling reasons, strongly resistant to any change.

In the end result, we still have a legal system which many might regard as needlessly obscure and expensive and which is in many ways unsuited to our needs. We also have the position that a great number of the profession and even of law teachers themselves would still deny that law is a fit subject for academic study.

\section{THE FUTURE OF THE REVOLUTION}

I believe that the great revolution cannot and will not be delayed much longer. Indeed, there are signs that it has already begun.

\section{Law Reform}

The most obvious first need is for a thorough overhaul of the law, with the object of rationalizing it and bringing it into the line with modern needs. This could be achieved in one of two ways. The first would be by a relaxation of the absolute doctrine of precedent in order to free the judges to make the necessary changes. This is, in part, the solution the Americans have adopted and, if it has its disadvantages, at least law in the United States seems in general to have adapted better to modern conditions than it has here. Lawyers present will know that the House of Lords, which is the highest court of appeal in England, recently issued a note stating that in future it would not be absolutely bound by its own decisions and this could be the start of a swing towards the American pattern. I know that many of us doubt whether the announcement is going to mean very much. This is because the American pattern contains other elements not yet present in England. For one thing, if judicial law reform is to be properly related to the needs of the community, our judges must be prepared to take account of, and hear argument on, other than strictly legal considerations. The 
Americans allow this, but a lifetime in the common law as it is known in England and New Zealand would almost inevitably dispose our practitioners and judges against such considerations. The other point is that ours is a unitary system whereas the United States contains some fifty different common law systems. American lawyers, particularly those from the national law schools, are, by their very training and environment, comparative lawyers. The knowledge that on many points different states have found differing solutions to the same problems, has instilled in them the habit of evaluating legal solutions by reference to more than merely legal criteria.

If this is the solution adopted in New Zealand, it is obvious that legal training will have to undergo considerable changes. I will return to this later.

The other possible solution would be a wholesale codification of the law. In this way, the whole body of case law could be swept away and our system, except in its procedural aspects, would then be not unlike that of the rest of the world. Bentham advocated this more than a hundred years ago. There are signs that something may be done at last. It is the avowed purpose of Lord Gardiner, the present Lord Chancellor of England, to bring about codification and to this end he has established bodies charged to achieve it. The great danger, as I see it, is that the task will be undertaken too lightly and within too narrow a frame of reference. To codify the common law rules as they exist would merely institutionalize an apparently arbitrary system. What is needed is a thorough reassessment of the law in terms of its policy and its effects. This would be an immense task. Only those specially qualified could be expected to accomplish it. Again, this must have implications for legal training.

\section{Legal Practice}

Another aspect of the revolution will, I believe, be a change in the nature of legal practice. We have already seen that, for most of its history, the common law has been a highly technical calling, practised by men with little more than a technical or trade training. Even today, legal employers are wont to say that non-professional employees of the type now called legal executives can be worth much more to them than a man with a university degree. Many members of the profession still cherish the belief that a person of average qualities is likely to make a more successful practitioner than will an able student. I do not doubt for a moment that there is an element of truth behind these assertions and the reason is not far to seek. A considerable proportion of what still goes on in legal offices can successfully be done by persons with no more than a technical or trade training. To a large extent, it is work of this kind, particularly in the conveyancing field, which provides the mainstay of legal practice. In saying this I am not in the least denigrating draftsmanship, which requires professional training and skill of the highest order. But I wonder how long the community is going to be content to pay professional fees for merely technical work. Conveyancing charges are generally made on a sliding scale so that comparisons are difficult to make. However, the scale for an hourly attendance is ten dollars. The comparable rate for an A grade mechanic is about two 
dollars. Is legal work worth five times a tradesman's rate if it can be done by someone with a comparable training?

During the last one hundred years, legal practice has adapted very little to changing conditions because, as I believe, the average practitioner has been ill-fitted by his training to so adapt. As a result, certain areas of legal practice have tended to pass out of the hands of the legal profession. Company and taxation work and estate planning have very largely passed to the accountants. The negotiation of contracts for the sale of land has largely been arrogated by the land agents. The commercial community tends to bring in a lawyer only in order to put into legal form contracts which have already been concluded. This stands in marked contrast to the position in America where a lawyer is brought into the decision-making process itself. In commerce, administration and public life, lawyers in New Zealand play nothing like the role they play in other countries.

It is quite possible that, by the end of this century, the legal profession's monopoly on conveyancing will have been broken. If this happens and if in other ways the more technical side of legal practice passes to others, the profession is going to have to live by the practice of purely professional skills. At the very least it may find itself having, like the medical profession before it, to accept a measure of specialization. These prospects, too, hold implications for legal education.

\section{Law Teaching}

Finally, as a result of all this, I believe there could well be a change in the status and function of the academic lawyer. At the moment, the academic lawyer in Australasia, as in England, has, for a jurist, a uniquely low status. I have tried to show the reasons for this. They go back to the character of the common law system as we practice it. It is a system in which the academic lawyer has no direct influence on law making. Such influence as he has is at second hand. The system is one which gives little place to the evaluative insights which academic study can supply. In these circumstances, it is not unnatural that the profession should place a low value on the academic's art. Elsewhere, however, the position is very different. In the United States, for example, the law teacher stands high. I am certain that one of the major reasons for this is that the system, as the Americans administer it, gives a place to the evaluation of legal doctrines. In civil law jurisdictions, the jurist often stands higher than the judge. The reason is that the source of law there is not the judge, but the code, and on this the jurist is every bit as well qualified to comment as is the judge. It therefore seems to me to follow that if this country should either abolish the stare decisis rule, or codify the common law, a change in the status of the academic lawyer is very likely to occur.

But in the meantime, whatever his status or lack of it, the law teacher of today has to remember that his students will be practising law well into the twenty-first century. Whether the changes I have predicted occur or not, at least we can be certain that there will be changes. It follows that at the very least we should be trying to foster in our students qualities of intellectual vigour and adaptability. But I do not believe we can stop there. If future lawyers are to play a fruitful role in the new society, we must also foster those special qualities which lawyers 
are by the nature of their calling best qualified to bring to affairs. I have in mind the part lawyers can play in decision making. Their profession is very largely concerned with the evaluation of data, the determination of what is and what is not relevant, the weight to be given to different factors and so on.

Nor have I forgotten that whatever their training in the law, legal practitioners are still going to have to practice. Law students and young practitioners are still in some way going to have to acquire the necessary technical skills. Sooner or later the New Zealand profession must ask itself whether the present method of training in such skills is good enough. The English and the Canadians have already started to do something about it. If the law societies here should ever feel a need to reconsider the matter, they will find the university law faculties more than willing to co-operate. The same would be true of programmes of further education.

If you are prepared to go any further with me, I believe law teachers have an even more important task, and that is to help to show New Zealand lawyers the way out of the ivory tower which the common law system has built around them. We can do this if we are prepared to open the law to scrutiny by the light of other disciplines. I have already mentioned some of these-sociology, anthropology, economics, history and political studies, in addition to philosophy and comparative law.

\section{The Difficulties Ahead}

But if all this is going to be achieved, law teachers are first going to have to convince themselves that it is necessary. And this will be no easy task. We are, all of us, equally with the legal practitioners, products of the old system. We have the same habits of thought and the same limited experience and training. It may be that the best today's generation of law teachers can hope to do is to generate a climate of enquiry and criticism, against which a new and better-trained generation of lawyers can perform the substantive task.

Next, the law teachers have got to persuade the community, as a whole, and the university community in particular, of the worth of what they are doing. I am hopeful that this particular battle is already more than half-way won and that the present position of New Zealand law faculties towards the bottom of the university stakes is the result of their history rather than of any other factor. The old system of training under which part-time students were taught by part-time teachers had a number of side effects. Under this system it was the law office, not the university, which was the students' focus. Staff-student contact was minimal. Teaching had to be restricted to lectures. In particular, there was no reason for the provision of law libraries. There were not enough full-time teachers to justify them, and few students would have thought of using them anyway. Accordingly, when the advent of full-time legal study and the greatly enlarged corps of professional law teachers at last made the provision of libraries essential, the New Zealand law schools had to start almost from scratch. The demands which the law faculties have had to make on the universities for library grants could easily be seen by other faculties as a mere attempt to improve what was al- 
ready adequate, at the expense of the rest of the university. In fact, the provision of an adequate library within a law school is something quite new in this country. In substance the need has been, and is still, to establish something which had no counterpart whatever under the old system. What is needed if the task is ever to be accomplished is not so much higher annual grants as sustained capital expenditure.

The other great legacy of the old system was in the matter of staffing. Where you had part-time students and part-time teachers, both with limited objectives, a low staff-student ratio was tolerable enough. That situation has now changed but, even so, the feeling may linger that law units can still be dismissed as half units, and that staff-student ratios are to be determined accordingly.

Finally, if we law teachers are to play our proper role, we must at least try to become better teachers. I think that for most teachers trained under the old system, the initial response to the new dispensation was and is to try to improve their courses by increasing their size and the amount of detail covered. But it is doubtful whether simply more of the mixture as before is very much of an advance. The dissemination of data is only a part of education. Accordingly, in the last five years or so, we have been experimenting at Auckland with different methods and approaches, with the idea of fostering a spirit of independence and enquiry.

We would be the first to admit that we still have a long way to go. But there is a dilemma to be faced here. If we go too far at this stage in anticipating changes in the legal system, we will run into strong resistance, not the least from the students themselves. On the other hand, if we do too little, we will have helped an unsatisfactory system to perpetuate itself.

I hope the new professor of law may be allowed to express a preference for the bolder course, even while he acknowledges, and no doubt demonstrates, that he is ill-equipped to follow it. 